Article

\title{
First Molecular Evidence for the Presence of Anaplasma phagocytophilum in Naturally Infected Small Ruminants in Tunisia, and Confirmation of Anaplasma ovis Endemicity
}

\author{
Youmna M'ghirbi ${ }^{1, *}\left(\mathbb{D}\right.$, Beatriz Oporto $^{2}$, Ana Hurtado ${ }^{2}\left(\mathbb{D}\right.$ and Ali Bouattour ${ }^{1}$ \\ 1 Laboratoire Virus, Vecteurs, Hôtes, Service d’Entomologie Médicale, Institut Pasteur de Tunis, Université \\ Tunis El Manar, Tunis 1002, Tunisia; ali.bouattour@pasteur.tn \\ 2 Department of Animal Health, NEIKER - Instituto Vasco de Investigación y Desarrollo Agrario, Basque \\ Research and Technology Alliance (BRTA), Bizkaia Science and Technology Park 812L, 48160 Derio, Bizkaia, \\ Spain; boporto@neiker.eus (B.O.); ahurtado@neiker.eus (A.H.) \\ * Correspondence: youmna.mghirbi@pasteur.tn
}

check for

updates

Citation: M'ghirbi, Y.; Oporto, B.;

Hurtado, A.; Bouattour, A. First

Molecular Evidence for the Presence of Anaplasma phagocytophilum in Naturally Infected Small Ruminants in Tunisia, and Confirmation of Anaplasma ovis Endemicity. Pathogens 2022, 11, 315. https://doi.org/ $10.3390 /$ pathogens 11030315

Academic Editors: Magdalena Zalewska and Emilia Bagnicka

Received: 24 January 2022

Accepted: 22 February 2022

Published: 3 March 2022

Publisher's Note: MDPI stays neutral with regard to jurisdictional claims in published maps and institutional affiliations.

Copyright: (C) 2022 by the authors. Licensee MDPI, Basel, Switzerland. This article is an open access article distributed under the terms and conditions of the Creative Commons Attribution (CC BY) license (https:// creativecommons.org/licenses/by/ $4.0 /)$.

\begin{abstract}
Anaplasma species are obligate intracellular rickettsial vector-borne pathogens that impose economic constraints on animal breeders and threaten human health. Anaplasma ovis and Anaplasma phagocytophilum infect sheep and goats worldwide. A duplex PCR targeting the msp2 and msp4 genes of A. phagocytophilum and A. ovis, respectively, was developed to analyze the field blood samples collected from sheep and goats. A total of 263 apparently healthy small ruminants from 16 randomly selected flocks situated in 3 bioclimatic zones in Tunisia were analyzed for Anaplasma infections. Anaplasma spp. was detected in 78.3\% (95\% confidence interval (CI): $72.8-83.1$ ) of the analyzed animals. The prevalence of $A$. ovis in sheep (80.4\%) and goats (70.3\%) was higher than that of $A$. phagocytophilum ( $7.0 \%$ in sheep and $1.6 \%$ in goats). Using an inexpensive, specific, and rapid duplex PCR assay, we provide, to the best of our knowledge, the first molecular evidence for the presence of A. phagocytophilum in small ruminants in Tunisia. A. phagocytophilum generally presented as a co-infection with $A$. ovis. This study provides important data to understand the epidemiology of anaplasmosis in small ruminants, and highlights the risk of contracting the infection upon tick exposure.
\end{abstract}

Keywords: Anaplasma phagocytophilum; Anaplasma ovis; small ruminants; duplex PCR assay; Tunisia

\section{Introduction}

The genus Anaplasma (order Rickettsiales; family Anaplasmataceae) includes ticktransmitted bacteria with veterinary and human health impacts [1]. Anaplasma spp. include ruminant species, such as Anaplasma ovis, which is an intraerythrocytic rickettsial pathogen of sheep, goats, and wild ruminants in several zones, including the Mediterranean region of Europe [2-4]. In general, the infection of animals with A. ovis is asymptomatic [5], however, severe clinical cases caused by this Anaplasma species have been reported [6]. Additionally, similar to other Anaplasma spp., infection with A. ovis may predispose animals to other infections and parasite infestations resulting in clinical disease and eventually death [7]. Recently, A. ovis became a potential zoonotic agent since the first documented human case was reported in a young woman with high fever in Cyprus [8].

The Anaplasma genus also includes A. phagocytophilum (previously known as Ehrlichia equi, Ehrlichia phagocytophila, and the human granulocytic ehrlichiosis agent), which infects a wide range of hosts, including humans, wild, and domesticated animals, and causes human, canine, and equine granulocytic anaplasmosis as well as tick-borne fever of ruminants [1]. Several mammalian hosts and ticks with persistent infection serve as reservoirs of $A$. phagocytophilum in nature [7]. 
In Tunisia, several studies detected the presence of various species of Anaplasma, such as A. phagocytophilum in horses and cattle; A. marginale, A. bovis, and A. centrale in cattle; A. ovis and $A$. platys-like in small ruminants; and A. platys in camels, dogs, and ticks [9-16]. These studies used several molecular biology tools. Therefore, to improve the diagnosis and the detection of small ruminant's anaplasmosis, we use in this study a molecular tool based on a single-step duplex PCR for the simultaneous detection and differentiation of A. ovis and $A$. phagocytophilum in small ruminants in Tunisia.

\section{Results}

\subsection{Duplex PCR Assay Performance}

From the template plasmids, $420 \mathrm{bp}$ and $334 \mathrm{bp}$ fragments of Anaplasma ovis and A. phagocytophilum, respectively, were generated. No amplification of the DNA from the uninfected sheep, used as a negative control, was observed. In addition, the DNA of A. marginale, A. platys, Ehrlichia sp., Ehrlichia canis, and Rickettsia conorii showed no amplification.

When present as single template plasmids, 1 copy of $A$. ovis and 10 copies of A. phagocytophilum were detected by the duplex PCR (Table 1). In mixed plasmid combinations, the detection limit was 10 copies for both species, even when the differences in their concentrations were of 2 orders of magnitude. The detection limit was the same when just the plasmid DNA was included and in the presence of uninfected host DNA (spiked controls).

Table 1. Duplex PCR assay sensitivity test: results of the amplification of different plasmid combinations and the DNA extracted from the blood of a non-infected sheep spiked with the same plasmid combinations.

\begin{tabular}{cccc}
\hline Plasmid Copies $^{\mathbf{a}}$ & $\begin{array}{c}\text { DNA Uninfected } \\
\text { Sheep }\end{array}$ & Anaplasma ovis & Anaplasma phagocytophilum \\
\hline $10^{3} \mathrm{Ap}+10 \mathrm{Ao}$ & $\mathrm{P}$ & Positive & Positive \\
$10^{3} \mathrm{Ap}+10 \mathrm{Ao}$ & $\mathrm{A}$ & Positive & Positive \\
$10 \mathrm{Ap}+\mathrm{Ao} 10^{3}$ & $\mathrm{P}$ & Positive & Positive \\
$10 \mathrm{Ap}+\mathrm{Ao} 10^{3}$ & $\mathrm{~A}$ & Positive & Positive \\
$10 \mathrm{Ap}$ & $\mathrm{P}$ & Negative & Positive \\
$10 \mathrm{Ap}$ & $\mathrm{A}$ & Negative & Positive \\
$1 \mathrm{Ap}$ & $\mathrm{P}$ & Negative & Negative \\
$1 \mathrm{Ap}$ & $\mathrm{A}$ & Positive & Negative \\
$10 \mathrm{Ao}$ & $\mathrm{P}$ & Positive & Negative \\
$10 \mathrm{Ao}$ & $\mathrm{A}$ & Positive & Negative \\
$1 \mathrm{Ao}$ & $\mathrm{P}$ & Positive & Negative \\
$1 \mathrm{Ao}$ & $\mathrm{A}$ & Negative
\end{tabular}

a: Ao, plasmid with an insert of the $m s p 4$ gene fragment of Anaplasma ovis; Ap, plasmid with an insert of the $m s p 2$ gene fragment of Anaplasma phagocytophilum. ${ }^{\mathrm{b}}$ : P, presence in the PCR reaction of DNA extracted from the blood from a non-infected sheep spiked with the indicated plasmid or plasmid combinations; A, absence of host DNA, water was used instead.

\subsection{Analysis of the Blood Samples Using the PCR Duplex Assay}

Using the duplex PCR, 78.3\% (206/263; 95\% confidence interval (CI): 72.8-83.1\%) of the tested small ruminants was positive to A. ovis and/or A. phagocytophilum (Table 2). A. ovis was detected in $77.9 \%(205 / 263 ; 95 \%$ CI: $72.4-82.8 \%)$ of analyzed animals with 80.4\% (160/199; 95\% CI: 74.2-85.7\%) infected sheep and 70.3\% (45/64; 95\% CI: 57.6-81.1\%) infected goats (Table 2). The difference of $A$. ovis infection between sheep and goats was not significant $(p=0.54)$. Similarly, no significant difference of $A$. ovis small ruminant infection rates $(p=0.08)$ was observed within the 3 bioclimatic zones: humid $(72.7 \%$; 95\% CI: 64.6-79.8\%), sub-humid (89.8\%; 95\% CI: 80.2-95.8\%), and semi-arid (76.5\%; 95\% CI: $62.5-87.2 \%)$. The prevalence of $A$. ovis in sheep flocks ranged from $53.8 \%(95 \%$ CI: $25.1-80.8 \%$ ) to $100 \%$ (95\% CI: $82.3-100 \%)$, with no significant difference ( $p=0.09)$ among the 3 bioclimatic zones. Similarly, the goat's prevalence in the different bioclimatic zones ranged from 54.3\% (95\% CI: 36.6-71.2\%) to 100\% (95\% CI: 69.1-100\%), with no significant 
difference $(p=0.58)$ in the 3 bioclimatic zones. In addition, no significant difference $(p=1.3)$ was recorded between $A$. ovis-infected adults $(82.8 \% ; 183 / 221 ; 95 \%$ CI: 77.2-85.5\%), and infected lambs and kids (22/42; 52.4\%; 95\% CI: 36.4-68.0\%).

Table 2. Duplex PCR detection and identification of Anaplasma ovis and Anaplasma pahgocytophilum in small ruminants in Northern Tunisia.

\begin{tabular}{|c|c|c|c|c|c|c|}
\hline \multirow{2}{*}{$\begin{array}{l}\text { Bioclimatic } \\
\text { Zone }\end{array}$} & \multirow{2}{*}{$\begin{array}{l}\text { Localities (n Animals: } \\
\text { Sheep: S, Goat: G) }\end{array}$} & \multirow{2}{*}{ Latitude; Longitude } & \multicolumn{2}{|c|}{ Sheep $(n=199)$} & \multicolumn{2}{|c|}{ Goats $(n=64)$} \\
\hline & & & A. ov (\%) & A. pha (\%) & A. ov (\%) & A.pha (\%) \\
\hline \multirow{5}{*}{ Humid } & Tabarka (17S, 4G) & $36.93557 ; 8.76174$ & $12(70.6)$ & $1(5.8)$ & $3(75.0)$ & 0 \\
\hline & Amdoun (24S) & $36.76783 ; 9.07399$ & $18^{\mathrm{a}}(75.0)$ & $1^{\mathrm{a}}(4.2)$ & ns & ns \\
\hline & Sejnene $(12 S, 35 G)$ & $37.13415 ; 9.26011$ & $10(83.3)$ & 0 & $19(54.3)$ & 0 \\
\hline & Maden $(28 S, 10 G)$ & $36.96668 ; 9.08898$ & $25(89.3)$ & 0 & $10(100.0)$ & 0 \\
\hline & Nefza (13S) & $36.98083 ; 9.08416$ & $7^{\mathrm{b}}(53.8)$ & $2^{b}(15.4)$ & ns & ns \\
\hline \multicolumn{2}{|c|}{ Total Humid $(94 S, 49 G)$} & & $72(76.6)$ & $4(8.2)$ & $32(65.3)$ & 0 \\
\hline \multirow{3}{*}{ Sub-Humid } & Oued El Abid (19S, 1G) & $36.86625 ; 10.74154$ & $19^{\mathrm{c}}(100.0)$ & $3^{c}(15.8)$ & $1(100.0)$ & 0 \\
\hline & Mellegue (11S) & $36.25407 ; 8.57642$ & $10^{\mathrm{d}}(90.9)$ & $5^{d}(45.5)$ & ns & ns \\
\hline & Touiref (38S) & $36.34741 ; 8.59298$ & $32(84.2)$ & 0 & $\mathrm{~ns}$ & ns \\
\hline \multicolumn{2}{|c|}{ Total Sub-Humid $(68 \mathrm{~S}, 1 \mathrm{G})$} & & $61(89.7)$ & $8(11.8)$ & $1(100.0)$ & 0 \\
\hline Semi-Arid & El Jouf (37S, 14G) & $36.31305 ; 10.10583$ & $27^{\mathrm{b}}(73.0)$ & $2^{b}(5.4)$ & $12^{\mathrm{e}}(85.7)$ & $1^{\mathrm{e}}(7.1)$ \\
\hline \multicolumn{2}{|c|}{ Total Semi-Arid $(37 \mathrm{~S}, 14 \mathrm{G})$} & & $27(73.0)$ & $2(5.4)$ & $12(85.7)$ & $1(7.1)$ \\
\hline Total & & & $160(80.4)$ & $14(7.0)$ & $45(70.3)$ & $1(1.6)$ \\
\hline
\end{tabular}

Superscripts denote the mixed infections with A. ovis and A. phagocytophilum: ${ }^{\mathrm{a}}$ in 1 sheep; ${ }^{\mathrm{b}}$ in 2 sheep; ${ }^{\mathrm{c}}$ in 3 sheep; ${ }^{\mathrm{d}}$ in 5 sheep; ${ }^{\mathrm{e}}$ in 1 goat; ns; not sampled.

Single infection by $A$. phagocytophilum was detected in 1 adult sheep $(0.4 \%$; $95 \%$ CI: $0.01-2.1 \%$ ). Otherwise, $A$. phagocytophilum was detected in combination with $A$. ovis in $5.3 \%$ (14/263; 95\% CI: 2.9-8.7\%) of animals (Table 2), i.e., 13 adult sheep (7\%; 95\% CI: 4-11.5\%) from the 3 investigated bioclimatic zones and 1 adult goat from the semi-arid zone $(1.6 \%$; 95\% CI: $0.04-8.4 \%$ ).

\section{Discussion}

Several molecular biology techniques were proposed for the identification of Anaplasmataceae species. Most of them target the heat shock gene groEL [17], the 23S rRNA [18], the 16S rRNA gene [19], and the major surface proteins (MSPs) [3]. In this study, using the $m s p 4$ and $m s p 2$ gene sequences, we successfully developed a specific and rapid duplex assay to differentiate $A$. phagocytophilum and $A$. ovis that does not require sophisticated laboratory equipment. Indeed, this optimized duplex PCR has the capability to specifically detect $A$. phagocytophilum and $A$. ovis from both single and mixed infections. The detection limit of the duplex PCR was the same for both species when present as a mixture (10 copies), but the sensitivity of the assay was better for A. ovis (1 copy) than for A. phagocytophilum (10 copies) for single infections. Moreover, our results show that the sensitivity of the PCR was the same in a single and a duplex format. This new assay adds to a similar one developed for the identification of the main Anaplasma species that infect cattle; by using the reverse primer designed here for A. ovis instead of the one for A. marginale (M4-Mar-R), the assay can be transformed to be used for small ruminants [20].

This study is the first report of the presence of $A$. phagocytophilum in small ruminants in Tunisia. However, previous studies, using molecular tools, detected A. phagocytophilum in cattle [20], dogs, horses, and ticks [14-16]. Our investigation shows that small ruminants in Tunisia were infected by $A$. ovis and A. phagocytophilum. The overall prevalence of Anaplasma spp. in small ruminants (78.3\%) was higher than that reported in Italy (42\%) [21], China (42\%) [22], Iran (34\%) [23], and Turkey (46.6\%) [24]. In fact, anaplasmosis is widely distributed throughout the world and the prevalence rates vary according to the region and the analysis technique used [25].

The average prevalence rate of $A$. ovis in sheep $(78 \%)$ was almost similar to that reported in other Tunisian regions (70-93.8\%) [13] and also in other countries, such as 
Portugal (82.5\%) [26]. In contrast, this rate was higher than those reported in other sites from northern Tunisia (35.6\%) [11], China (40.5\%) [22], Sudan (41.7\%) [27], Turkey (31.4\%) [26], and Iran (44\%) [23]. The study herein did not find significant differences in the prevalence of A. ovis in sheep (80.4\%) and goats (70.3\%). In contrast, using PCR targeting $16 \mathrm{~S}$ rRNA gene, Belkahia et al. [11] reported lower prevalence in other regions in Tunisia (35.6\%). In addition, lower prevalences were reported in China (15.3-25.6\%) $[28,29]$, and recently in Turkey (45.7\% in sheep and 50\% in goats) [24]. In fact, this high $A$. ovis prevalence rate fits well with our previously data, which reported that $95.5 \%$ of ticks collected from ruminants in the studied regions were Rhipicephalus turanicus [30], the tick species considered the vector of A. ovis. Indeed, DNA of A. ovis was detected in most of this and other Rhipicephalus species in Tunisia [31], Italy [32], Algeria [33], and France [34]. In addition, several other tick species, belonging to Rhipicephalus, Hyalomma, and Dermacentor genera, were previously reported as probable vectors of $A$. ovis worldwide [35,36]. Likewise, other arthropod species can be involved in the transmission of $A$. ovis [37]. In this context, the role of the biting hematophagous insects, such as Hippoboscidae flies [38,39], infesting sheep and occasionally goats, and some species of fleas [40] should not be underestimated with regard to the transmission of anaplasmosis.

The differences in the prevalence rates of $A$. ovis in small ruminants recorded in the different regions may be due to several factors, such as the presence and the abundance of ticks, methods used for sample analysis, wildlife reservoir presence [32], the management of farms and husbandry practices, bioclimatic and ecological parameters, and susceptibility of host species and breeds. In addition, goats are known to spend less time grazing and graze just within the home boundaries compared to sheep that graze far into the bush, hence coming into contact with vegetation and subsequently more ectoparasites.

Anaplasma phagocytophilum was detected in small ruminants in Tunisia for the first time. However, it was less frequently detected in sheep in this study compared to studies carried out in Northern Slovakia [41], China [42], and Turkey [43]. This low prevalence could be explained by (i) the low number of intragranulocytic A. phagocytophilum circulating in carriers animals [44]; (ii) the low tick infection rate by A. phagocytophilum; and (iii) the short duration of A. phagocytophilum bacteremia during the acute phase of infection [45-47]. In Tunisia, A. phagocytophilum was reported in the humid and sub-humid investigated zones in which Ixodes ricinus, the main vector of $A$. phagocytophilum in Europe [48,49], occurred [50].

Interestingly, A. phagocytophilum was detected in three small ruminants from the semi-arid zone in which Ixodes icinus is absent, suggesting that this bacterium is probably maintained in foci by other Ixodidae. Indeed, Estrada-Peña [51] reported that other Ixodidae species of the genera Hyalomma, Rhipicephalus, and Haemaphysalis are potential vectors of A. phagocytophilum. In the investigated semi-arid regions, these tick genera heavily infested ruminants $[50,52]$. These results support the idea that several tick species may maintain or be involved in the transmission of $A$. phagocytophilum.

In this study, we observed mixed infections with A. phagocytophilum and A. ovis in sheep and goats, which suggests that Tunisia is a country with endemic occurrence of pasture fever, gradually spreading from humid to semi-arid sites. This agreed with the results reported in southeastern and northern Slovakia, but contradicted the study carried out in northwestern China [53]. In Italy, [21] a high occurrence of mixed infection with A. phagocytophilum and A. ovis was detected in a sheep flock with health issues. Similar results were recorded in Slovakia [54], Turkey [24], Germany [55], and China [56]. A description of the coinfection of small ruminants in Tunisia with more than one pathogen has already been reported [30]. Coinfection favors health problems of the animals and can consequently increase the loss of productivity [57]. Authors speculated that immunosuppressed animals with poor health conditions are more vulnerable to the multiple Anaplasma infections. Finally, A. phagocytophilum and A. ovis circulate within small ruminant populations across Mediterranean countries, but the extent of infection seems to vary among countries. These variations may be related to climate conditions, different husbandry systems, and the occurrence of these species in the tick population. 


\section{Materials and Methods}

\subsection{Design of Primers}

To design the primers, Vector NTI 8.0 software (Informax Inc., North Bethesda, MD, USA) was used to align $A$. ovis $m s p 4$ and $A$. phagocytophilum $m s p 2$ gene sequences with those of other Anaplasma and Ehrlichia species. Then, a new reverse primer (M4-Ov-R: 5'-ATGTCCTTGTAAGACTCGTCAAAGAGT-3') was designed to be used with the forward primer M4-OvMar-F described elsewhere [20], in order to specifically amplify a $420 \mathrm{bp}$ fragment of the $m s p 4$ gene of $A$. ovis. These primers were used in combination with the previously designed primers that amplify a $334 \mathrm{bp}$ fragment of the msp2 gene of A. phagocytophilum [58].

\subsection{Cloning and Sequencing the msp4 A. ovis Gene and the msp2 A. phagocytophilum Gene}

DNA extracted from two naturally infected sheep with A. ovis and A. phagocytophilum using QIAamp DNA Mini Kit (QIAGEN, Hilden, Germany) as per the manufacturer's recommendations was used as a template to amplify a $420 \mathrm{bp}$ and $334 \mathrm{bp}$ of $m s p 4$ and msp2 genes, respectively. A pCR4-TOPO vector was used to clone the amplified products according to the manufacturer's instructions (TOPO TA cloning kit for sequencing; Invitrogen, Carlsbad, CA, USA). Recombinant plasmid DNA was purified using a FlexiPrep kit (Amersham Biosciences, Freiburg, Germany), subjected to automatic dye terminator cycle sequencing, and the nucleotide sequences of the plasmid inserts were confirmed as A. phagocytophilum and A. ovis using Blast (https://blast.ncbi.nlm.nih.gov/Blast; accessed on 30 June 2019).

The plasmid concentrations were controlled using a NanoDrop ND-1000 spectrophotometer (Thermo Scientific, Germany) and the plasmids were 10-fold serially diluted from $10^{8}$ to 10 copies $/ \mu \mathrm{L}$ in a Tris-EDTA buffer. The sensitivity of the assay was tested using serial dilutions of individual plasmids as well as different combinations of both plasmids.

\subsection{Duplex PCR Amplification}

A commercially available Multiplex-PCR assay kit (QIAGEN, Hilden, Germany) was used to perform PCR reactions in $25 \mu \mathrm{L}$ volume reactions, including $1 \times$ QIAGEN Multiplex PCR Master Mix (QIAGEN, CA), $0.5 \mu \mathrm{M}$ of Msp2-3F/Msp2-3R primers, $0.2 \mu \mathrm{M}$ M4-OvMar$\mathrm{F} / \mathrm{M} 4-\mathrm{Ov}-\mathrm{R}$ primers, and 10 to $50 \mathrm{ng} / \mu \mathrm{L}$ of extracted DNA. The qPCR program was the following: $15 \mathrm{~min}$ at $95{ }^{\circ} \mathrm{C}$, followed by 40 cycles at $94{ }^{\circ} \mathrm{C}$ for $30 \mathrm{~s}, 63^{\circ} \mathrm{C}$ for $90 \mathrm{~s}, 72{ }^{\circ} \mathrm{C}$ for $90 \mathrm{~s}$, and a final step at $72{ }^{\circ} \mathrm{C}$ for $10 \mathrm{~min}$. To avoid false-positive reactions and crosscontaminations, PCR reactions were set up in a separate room, plugged tips were used, and a negative (water) control was included in each run.

\subsection{Analysis of the Sensitivity and Specificity of Single and Duplex PCR Assay}

Ten-fold serial dilutions of individual plasmids with the two inserts of A. phagocytophilum and $A$. ovis as well as different combinations were amplified, as described above, to determine the detection limit of the single and the duplex PCR assays. In addition, sensitivity was tested using an extracted DNA from blood of a non-infected sheep spiked with the same plasmid combinations. DNA from other Rickettsiale species (Anaplasma marginale, Anaplasma platys, Ehrlichia sp., Ehrlichia canis, and Rickettsia conorii) were used to test the specificity of the PCR assays.

\subsection{Study Sites, Blood Sampling, and DNA Extraction}

This cross-sectional study was conducted in 2015 in 9 localities (Table 2) situated in 3 different bioclimatic zones (humid, sub-humid, and semi-arid) in northern Tunisia (Table 2). All sites have a Mediterranean climate: cool, moist winters and dry, hot summers. Sheep and goat flocks were randomly chosen following the recommendations of the State Veterinary Office as representative of the local traditional management system, with small flocks grazing on permanent pastures or bush. Animals $(n=263)$ were selected from 16 flocks, including 199 Barbarine sheep (193 females and 6 males) and 64 goat females of 
local breed (Table 2). Among these animals, 42 were younger than 1 year (26 lambs, 16 kids) and 221 were adults (173 sheep, 48 goats). These small ruminants were bled once between April and June 2015 during the season of tick activity.

DNA was extracted from the blood using the PureLink Genomic DNA Kit for DNA purification (Invitrogen, Carlsbad, CA, USA) and yields were determined using a NanoDrop ND-1000 Spectrophotometer (Thermo Scientific, Dreieich, Germany). Extracted DNA was tested for the presence of $A$. ovis and A. phagocytophilum using the duplex PCR assay as described above. Amplified fragments were subjected to electrophoresis on a 1.5\% agarose gel stained with GelRed Nucleic Acid Gel Stain (Biotium, Koln, France), and then visualized by UV transillumination.

\subsection{Statistical Analysis}

The chi-squared or Fisher's exact tests were used to compare the proportions of positivity by the host (sheep and goats) in the three bioclimatic zones and age groups (adult vs. lamb/kid). The $p$-values of 0.05 or less were considered statistically significant.

\section{Conclusions}

We presented here the first molecular evidence for the presence of A. phagocytophilum in naturally infected small ruminants in Tunisia, and confirmed that $A$. ovis is endemic in the different bioclimatic zones of Tunisia. The occurrence of A. phagocytophilum in small ruminants was rare and it generally presented as a mixed infection with $A$. ovis. These results deserve more attention and highlight the need to investigate other farming regions to understand the epidemiology of anaplasmosis, since A. phagocytophilum prevalence is certainly underestimated in Tunisia. In addition to the threats that granulocytic anaplasmosis might pose to livestock in Tunisia, A. phagocytophilum and A. ovis can have adverse effects on human health. Therefore, the zoonotic potential of these species should no longer be neglected, especially as the epidemiology of human granulocytic anaplasmosis is still unknown in North Africa. Furthermore, the investigation of their clinical impact, particularly in case of comorbidities and of potential tick vectors is useful to understand the life cycle and promote a One Health approach to prevent and control the infection.

Author Contributions: Conceptualization, A.H. and A.B.; methodology, Y.M. and B.O.; software, Y.M.; validation, Y.M.; formal analysis, Y.M.; investigation, Y.M. and A.B.; data curation, Y.M.; writing—original draft preparation, Y.M.; writing—review and editing, Y.M., A.B., B.O. and A.H.; visualization, A.B., Y.M. and A.H.; supervision, A.B. and A.H.; project administration, Y.M., A.B., B.O. and A.H.; funding acquisition, Y.M., A.B. and A.H. All authors have read and agreed to the published version of the manuscript.

Funding: This research was funded by the Spanish Agency for International Development Cooperation (AECID, Projects No. A/026818/09 and A/031009/10), the Spanish National Institute for Agricultural and Food Research and Technology (INIA, Project No. RTA2009-000-18-00-00), the European Regional Development Fund (ERDF), and the Ministry for Higher Education, Scientific Research, and Technology in Tunisia.

Institutional Review Board Statement: The study has been approved by the Commission on Ethics and Animal Welfare of the Institut Pasteur de Tunis-Université Tunis El Manar-TUNISIA with the given number 2014/03/I/LR11IPT03/V1. All technical procedures were in accordance with the National and the European legislation regarding animal welfare and have met the International Guiding Principles for Biomedical Research Involving Animals by the Council for the International Organizations of Medical Sciences.

Informed Consent Statement: Not applicable.

Data Availability Statement: Not applicable.

Acknowledgments: We are grateful to Leila Saieh, Kamel Khlif, Zouheir Ktata, Ridha Ben Omrane, and Adel Rhim for their help in field work. The authors would also thank the farmers for their collaboration in sample collection. 
Conflicts of Interest: The authors declare no conflict of interest. The funders had no role in the design of the study; in the collection, analyses, or interpretation of data; in the writing of the manuscript, or in the decision to publish the results.

\section{References}

1. Dumler, J.S.; Barbet, A.F.; Bekker, C.P.; Dasch, G.A.; Palmer, G.H.; Ray, S.C.; Rikihisa, Y.; Rurangirwa, F.R. Reorganization of Genera in the Families Rickettsiaceae and Anaplasmataceae in the Order Rickettsiales: Unification of Some Species of Ehrlichia with Anaplasma, Cowdria with Ehrlichia and Ehrlichia with Neorickettsia, Descriptions of Six New Species Combinations and Designation of Ehrlichia Equi and "HGE Agent" as Subjective Synonyms of Ehrlichia Phagocytophila. Int. J. Syst. Evol. Microbiol. 2001, 51, 2145-2165. [CrossRef] [PubMed]

2. Chochlakis, D.; Ioannou, I.; Sharif, L.; Kokkini, S.; Hristophi, N.; Dimitriou, T.; Tselentis, Y.; Psaroulaki, A. Prevalence of Anaplasma Sp. in Goats and Sheep in Cyprus. Vector-Borne Zoonotic Dis. 2009, 9, 457-463. [CrossRef] [PubMed]

3. de la Fuente, J.; Atkinson, M.W.; Naranjo, V.; Fernández de Mera, I.G.; Mangold, A.J.; Keating, K.A.; Kocan, K.M. Sequence Analysis of the Msp4 Gene of Anaplasma Ovis Strains. Vet. Microbiol. 2007, 119, 375-381. [CrossRef] [PubMed]

4. Torina, A.; Vicente, J.; Alongi, A.; Scimeca, S.; Turlá, R.; Nicosia, S.; Di Marco, V.; Caracappa, S.; de la Fuente, J. Observed Prevalence of Tick-Borne Pathogens in Domestic Animals in Sicily, Italy during 2003-2005. Zoonoses Public Health 2007, 54, 8-15. [CrossRef] [PubMed]

5. Splitter, E.J.; Anthony, H.D.; Twiehaus, M.J. Anaplasma Ovis in the United States; Experimental Studies with Sheep and Goats. Am. J. Vet. Res. 1956, 17, 487-491.

6. Tibbitts, T.; Goff, W.; Foreyt, W.; Stiller, D. Susceptibility of Two Rocky Mountain Bighorn Sheep to Experimental Infection with Anaplasma Ovis. J. Wildl. Dis. 1992, 28, 125-129. [CrossRef]

7. Kocan, K.M.; de la Fuente, J.; Blouin, E.F.; Garcia-Garcia, J.C. Anaplasma Marginale (Rickettsiales: Anaplasmataceae): Recent Advances in Defining Host-Pathogen Adaptations of a Tick-Borne Rickettsia. Parasitology 2004, 129 (Suppl. S1), S285-S300. [CrossRef]

8. Chochlakis, D.; Ioannou, I.; Tselentis, Y.; Psaroulaki, A. Human Anaplasmosis and Anaplasma Ovis Variant. Emerg. Infect. Dis. 2010, 16, 1031-1032. [CrossRef]

9. Belkahia, H.; Said, M.B.; Sayahi, L.; Alberti, A.; Messadi, L. Detection of Novel Strains Genetically Related to Anaplasma Platys in Tunisian One-Humped Camels (Camelus Dromedarius). J. Infect. Dev. Ctries. 2015, 9, 1117-1125. [CrossRef]

10. Belkahia, H.; Ben Said, M.; Alberti, A.; Abdi, K.; Issaoui, Z.; Hattab, D.; Gharbi, M.; Messadi, L. First Molecular Survey and Novel Genetic Variants' Identification of Anaplasma Marginale, A. Centrale and A. Bovis in Cattle from Tunisia. Infect. Genet. Evol. 2015, 34, 361-371. [CrossRef]

11. Belkahia, H.; Ben Said, M.; El Mabrouk, N.; Saidani, M.; Cherni, C.; Ben Hassen, M.; Bouattour, A.; Messadi, L. Seasonal Dynamics, Spatial Distribution and Genetic Analysis of Anaplasma Species Infecting Small Ruminants from Northern Tunisia. Infect. Genet. Evol. 2017, 54, 66-73. [CrossRef] [PubMed]

12. Ben Said, M.; Belkahia, H.; Karaoud, M.; Bousrih, M.; Yahiaoui, M.; Daaloul-Jedidi, M.; Messadi, L. First Molecular Survey of Anaplasma Bovis in Small Ruminants from Tunisia. Vet. Microbiol. 2015, 179, 322-326. [CrossRef] [PubMed]

13. Ben Said, M.; Belkahia, H.; Alberti, A.; Zobba, R.; Bousrih, M.; Yahiaoui, M.; Daaloul-Jedidi, M.; Mamlouk, A.; Gharbi, M.; Messadi, L. Molecular Survey of Anaplasma Species in Small Ruminants Reveals the Presence of Novel Strains Closely Related to A. Phagocytophilum in Tunisia. Vector-Borne Zoonotic Dis. 2015, 15, 580-590. [CrossRef] [PubMed]

14. M'ghirbi, Y.; Ghorbel, A.; Amouri, M.; Nebaoui, A.; Haddad, S.; Bouattour, A. Clinical, Serological, and Molecular Evidence of Ehrlichiosis and Anaplasmosis in Dogs in Tunisia. Parasitol. Res. 2009, 104, 767-774. [CrossRef] [PubMed]

15. M'ghirbi, Y.; Yaïch, H.; Ghorbel, A.; Bouattour, A. Anaplasma Phagocytophilum in Horses and Ticks in Tunisia. Parasit. Vectors 2012, 5, 180. [CrossRef] [PubMed]

16. Sarih, M.; M'Ghirbi, Y.; Bouattour, A.; Gern, L.; Baranton, G.; Postic, D. Detection and Identification of Ehrlichia Spp. in Ticks Collected in Tunisia and Morocco. J. Clin. Microbiol. 2005, 43, 1127-1132. [CrossRef] [PubMed]

17. Park, H.-S.; Lee, J.-H.; Jeong, E.-J.; Park, T.-K.; Kim, T.-Y.; Chae, J.-S.; Park, J.-H.; Klein, T.A.; Jang, W.-J.; Park, K.-H.; et al. Differentiation of Anaplasmataceae through Partial GroEL Gene Analysis. Microbiol. Immunol. 2005, 49, 655-662. [CrossRef]

18. Dahmani, M.; Davoust, B.; Benterki, M.S.; Fenollar, F.; Raoult, D.; Mediannikov, O. Development of a New PCR-Based Assay to Detect Anaplasmataceae and the First Report of Anaplasma Phagocytophilum and Anaplasma Platys in Cattle from Algeria. Comp. Immunol. Microbiol. Infect. Dis. 2015, 39, 39-45. [CrossRef] [PubMed]

19. Parola, P.; Cornet, J.-P.; Sanogo, Y.O.; Miller, R.S.; Thien, H.V.; Gonzalez, J.-P.; Raoult, D.; Telford, S.R., III; Wongsrichanalai, C. Detection of Ehrlichia Spp., Anaplasma Spp., Rickettsia Spp., and Other Eubacteria in Ticks from the Thai-Myanmar Border and Vietnam. J. Clin. Microbiol. 2003, 41, 1600-1608. [CrossRef]

20. M'ghirbi, Y.; Bèji, M.; Oporto, B.; Khrouf, F.; Hurtado, A.; Bouattour, A. Anaplasma Marginale and A. Phagocytophilum in Cattle in Tunisia. Parasit. Vectors 2016, 9, 556. [CrossRef] [PubMed]

21. Torina, A.; Galindo, R.C.; Vicente, J.; Di Marco, V.; Russo, M.; Aronica, V.; Fiasconaro, M.; Scimeca, S.; Alongi, A.; Caracappa, S.; et al. Characterization of Anaplasma Phagocytophilum and A. Ovis Infection in a Naturally Infected Sheep Flock with Poor Health Condition. Trop. Anim. Health Prod. 2010, 42, 1327-1331. [CrossRef] [PubMed] 
22. Yang, J.; Li, Y.; Liu, Z.; Liu, J.; Niu, Q.; Ren, Q.; Chen, Z.; Guan, G.; Luo, J.; Yin, H. Molecular Detection and Characterization of Anaplasma Spp. in Sheep and Cattle from Xinjiang, Northwest China. Parasit. Vectors 2015, 8, 108. [CrossRef] [PubMed]

23. Soosaraei, M.; Haghi, M.M.; Etemadifar, F.; Fakhar, M.; Teshnizi, S.H.; Asfaram, S.; Esboei, B.R. Status of Anaplasma Spp. Infection in Domestic Ruminants from Iran: A Systematic Review with Meta-Analysis. Parasite Epidemiol. Control 2020, 11 , e00173. [CrossRef] [PubMed]

24. Benedicto, B.; Ceylan, O.; Moumouni, P.F.A.; Lee, S.-H.; Tumwebaze, M.A.; Li, J.; Galon, E.M.; Liu, M.; Li, Y.; Ji, S.; et al. Molecular Detection and Assessment of Risk Factors for Tick-Borne Diseases in Sheep and Goats from Turkey. Acta Parasitol. 2020, 65, 723-732. [CrossRef]

25. Ben Said, M.; Belkahia, H.; Messadi, L. Anaplasma Spp. in North Africa: A Review on Molecular Epidemiology, Associated Risk Factors and Genetic Characteristics. Ticks Tick Borne Dis. 2018, 9, 543-555. [CrossRef]

26. Renneker, S.; Abdo, J.; Salih, D.E.A.; Karagenç, T.; Bilgiç, H.; Torina, A.; Oliva, A.G.; Campos, J.; Kullmann, B.; Ahmed, J.; et al. Can Anaplasma Ovis in Small Ruminants Be Neglected Any Longer? Transbound. Emerg. Dis. 2013, 60 (Suppl. S2), 105-112. [CrossRef]

27. Renneker, S.; Abdo, J.; Bakheit, M.A.; Kullmann, B.; Beyer, D.; Ahmed, J.; Seitzer, U. Coinfection of Sheep with Anaplasma, Theileria and Babesia Species in the Kurdistan Region, Iraq. Transbound. Emerg. Dis. 2013, 60 (Suppl. S2), 113-118. [CrossRef]

28. Chi, Q.; Liu, Z.; Li, Y.; Yang, J.; Chen, Z.; Yue, C.; Luo, J.; Yin, H. Development of a Real-Time PCR Assay for Detection and Quantification of Anaplasma Ovis Infection. Transbound. Emerg. Dis. 2013, 60, 119-124. [CrossRef]

29. Liu, Z.; Ma, M.; Wang, Z.; Wang, J.; Peng, Y.; Li, Y.; Guan, G.; Luo, J.; Yin, H. Molecular Survey and Genetic Identification of Anaplasma Species in Goats from Central and Southern China. Appl. Environ. Microbiol. 2012, 78, 464-470. [CrossRef]

30. M'ghirbi, Y.; Ros-García, A.; Iribar, P.; Rhaim, A.; Hurtado, A.; Bouattour, A. A Molecular Study of Tick-Borne Haemoprotozoan Parasites (Theileria and Babesia) in Small Ruminants in Northern Tunisia. Vet. Parasitol. 2013, 198, 72-77. [CrossRef]

31. Belkahia, H.; Ben Said, M.; Ghribi, R.; Selmi, R.; Ben Asker, A.; Yahiaoui, M.; Bousrih, M.; Daaloul-Jedidi, M.; Messadi, L. Molecular Detection, Genotyping and Phylogeny of Anaplasma Spp. in Rhipicephalus Ticks from Tunisia. Acta Trop. 2019, 191, 38-49. [CrossRef]

32. Torina, A.; Alongi, A.; Naranjo, V.; Scimeca, S.; Nicosia, S.; Di Marco, V.; Caracappa, S.; Kocan, K.M.; de la Fuente, J. Characterization of Anaplasma Infections in Sicily, Italy. Ann. N. Y. Acad. Sci. 2008, 1149, 90-93. [CrossRef] [PubMed]

33. Aouadi, A.; Leulmi, H.; Boucheikhchoukh, M.; Benakhla, A.; Raoult, D.; Parola, P. Molecular Evidence of Tick-Borne Hemoprotozoan-Parasites (Theileria Ovis and Babesia Ovis) and Bacteria in Ticks and Blood from Small Ruminants in Northern Algeria. Comp. Immunol. Microbiol. Infect. Dis. 2017, 50, 34-39. [CrossRef] [PubMed]

34. Dahmani, M.; Davoust, B.; Tahir, D.; Raoult, D.; Fenollar, F.; Mediannikov, O. Molecular Investigation and Phylogeny of Anaplasmataceae Species Infecting Domestic Animals and Ticks in Corsica, France. Parasit. Vectors 2017, 10, 302. [CrossRef] [PubMed]

35. Friedhoff, K.T. Tick-Borne Diseases of Sheep and Goats Caused by Babesia, Theileria or Anaplasma spp. Parassitologia 1997, 39, 99-109.

36. Yin, H.; Luo, J. Ticks of Small Ruminants in China. Parasitol. Res. 2007, 101, 187-189. [CrossRef]

37. Uilenberg, G. General Review of Tick-Borne Diseases of Sheep and Goats World-Wide. Parassitologia 1997, 39, 161-165.

38. Hashemi-Fesharki, R. Tick-Borne Diseases of Sheep and Goats and Their Related Vectors in Iran. Parassitologia 1997, $39,115-117$.

39. Hornok, S.; de la Fuente, J.; Biró, N.; Fernández de Mera, I.G.; Meli, M.L.; Elek, V.; Gönczi, E.; Meili, T.; Tánczos, B.; Farkas, R.; et al. First Molecular Evidence of Anaplasma Ovis and Rickettsia Spp. in Keds (Diptera: Hippoboscidae) of Sheep and Wild Ruminants. Vector-Borne Zoonotic Dis. 2011, 11, 1319-1321. [CrossRef]

40. Da Silva, A.S.; Lopes, L.S.; Diaz, J.D.S.; Tonin, A.A.; Stefani, L.M.; Araújo, D.N. Lice Outbreak in Buffaloes: Evidence of Anaplasma Marginale Transmission by Sucking Lice Haematopinus Tuberculatus. J. Parasitol. 2013, 99, 546-547. [CrossRef]

41. Derdáková, M.; Stefančíková, A.; Spitalská, E.; Taragel’ová, V.; Košt’álová, T.; Hrkl’ová, G.; Kybicová, K.; Schánilec, P.; Majláthová, V.; Várady, M.; et al. Emergence and Genetic Variability of Anaplasma Species in Small Ruminants and Ticks from Central Europe. Vet. Microbiol. 2011, 153, 293-298. [CrossRef] [PubMed]

42. Zhan, L.; Cao, W.C.; Jiang, J.F.; Zhang, X.A.; Liu, Y.X.; Wu, X.M.; Zhang, W.Y.; Zhang, P.H.; Bian, C.L.; Dumler, J.S.; et al. Anaplasma Phagocytophilum from Rodents and Sheep, China. Emerg. Infect. Dis. 2010, 16, 764-768. [CrossRef] [PubMed]

43. Aktaş, M.; Özübek, S.; Uluçeşme, M.C. Molecular Detection and Phylogeny of Anaplasma Phagocytophilum and Related Variants in Small Ruminants from Turkey. Animals 2021, 11, 814. [CrossRef] [PubMed]

44. Pusterla, N.; Huder, J.; Wolfensberger, C.; Litschi, B.; Parvis, A.; Lutz, H. Granulocytic Ehrlichiosis in Two Dogs in Switzerland. J. Clin. Microbiol. 1997, 35, 2307-2309. [CrossRef] [PubMed]

45. Ogden, N.H.; Casey, A.N.J.; French, N.P.; Bown, K.J.; Adams, J.D.W.; Woldehiwet, Z. Natural Ehrlichia Phagocytophila Transmission Coefficients from Sheep "carriers" to Ixodes Ricinus Ticks Vary with the Numbers of Feeding Ticks. Parasitology 2002, 124, 127-136. [CrossRef] [PubMed]

46. Ogden, N.H.; Casey, A.N.J.; Woldehiwet, Z.; French, N.P. Transmission of Anaplasma Phagocytophilum to Ixodes Ricinus Ticks from Sheep in the Acute and Post-Acute Phases of Infection. Infect. Immun. 2003, 71, 2071. [CrossRef] [PubMed]

47. Palmer, G.H.; Abbott, J.R.; French, D.M.; McElwain, T.F. Persistence of Anaplasma Ovis Infection and Conservation of the Msp-2 and Msp-3 Multigene Families within the Genus Anaplasma. Infect. Immun. 1998, 66, 6035-6039. [CrossRef] 
48. Parola, P.; Beati, L.; Cambon, M.; Brouqui, P.; Raoult, D. Ehrlichial DNA Amplified from Ixodes Ricinus (Acari: Ixodidae) in France. J. Med. Entomol. 1998, 35, 180-183. [CrossRef]

49. Petrovec, M.; Sumner, J.W.; Nicholson, W.L.; Childs, J.E.; Strle, F.; Barlic, J.; Lotric-Furlan, S.; Avsic Zupanc, T. Identity of Ehrlichial DNA Sequences Derived from Ixodes Ricinus Ticks with Those Obtained from Patients with Human Granulocytic Ehrlichiosis in Slovenia. J. Clin. Microbiol. 1999, 37, 209-210. [CrossRef]

50. Bouattour, A.; Darghouth, M.A.; Daoud, A. Distribution and Ecology of Ticks (Acari: Ixodidae) Infesting Livestock in Tunisia: An Overview of Eighth Years Field Collections. Parassitologia 1999, 41 (Suppl. S1), 5-10.

51. Ticks of Domestic Animals in the Mediterranean Region. A Guide to Identification of Species. Available online: https:/ / www.researchgate.net/publication/259576176_Ticks_of_Domestic_Animals_in_the_Mediterranean_Region_A_ Guide_to_Identification_of_Species (accessed on 7 January 2022).

52. M'ghirbi, Y.; Hurtado, A.; Bouattour, A. Theileria and Babesia Parasites in Ticks in Tunisia. Transbound. Emerg. Dis. 2010, 57, 49-51. [CrossRef] [PubMed]

53. Yang, J.; Liu, Z.; Niu, Q.; Liu, J.; Han, R.; Guan, G.; Li, Y.; Liu, G.; Luo, J.; Yin, H. Anaplasma Phagocytophilum in Sheep and Goats in Central and Southeastern China. Parasit. Vectors 2016, 9, 593. [CrossRef]

54. Víchová, B.; Majláthová, V.; Nováková, M.; Stanko, M.; Hviščová, I.; Pangrácová, L.; Chrudimský, T.; Čurlík, J.; Petko, B. Anaplasma Infections in Ticks and Reservoir Host from Slovakia. Infect. Genet. Evol. 2014, 22, 265-272. [CrossRef] [PubMed]

55. Bauer, B.U.; Răileanu, C.; Tauchmann, O.; Fischer, S.; Ambros, C.; Silaghi, C.; Ganter, M. Anaplasma Phagocytophilum and Anaplasma Ovis-Emerging Pathogens in the German Sheep Population. Pathogens 2021, 10, 1298. [CrossRef]

56. Yang, B.; Sun, E.; Wen, Y.; Ye, C.; Liu, F.; Jiang, P.; Tao, X. Molecular Evidence of Coinfection of Anaplasma Species in Small Ruminants from Anhui Province, China. Parasitol. Int. 2019, 71, 143-146. [CrossRef] [PubMed]

57. Sayin, F.; Dyncer, S.; Karaer, Z.; Cakmak, A.; Yukary, B.A.; Eren, H.; Deger, S.; Nalbantoglu, S. Status of the Tick-Borne Diseases in Sheep and Goats in Turkey. Parassitologia 1997, 39, 153-156.

58. Zeidner, N.S.; Burkot, T.R.; Massung, R.; Nicholson, W.L.; Dolan, M.C.; Rutherford, J.S.; Biggerstaff, B.J.; Maupin, G.O. Transmission of the Agent of Human Granulocytic Ehrlichiosis by Ixodes Spinipalpis Ticks: Evidence of an Enzootic Cycle of Dual Infection with Borrelia Burgdorferi in Northern Colorado. J. Infect. Dis. 2000, 182, 616-619. [CrossRef] 